\title{
Pelatihan Deteksi Dini Kanker Mulut dengan SAMURI pada Komunitas Penyintas Kanker Love and Healthy Tangerang
}

DOI: https://doi.org/10.32509/abdimoestopo.v5i1.1749

\begin{abstract}
Rahmi Amtha*, Komariah, Dewi Priandini, Muhammad Orliando Roeslan, Firstine Kelsi, Rahma Landy Dewi Agustini, IG Sanditya Ardiana, Ilona Krista J., Stephanie Ayu Budi K
\end{abstract}

\author{
Fakultas Kedokteran Gigi Universitas Trisakti. \\ Jl. Kayi Tapa Grogol 260 Jakarta Barat 11441, Indonesia \\ *Email korespodensi : rahmi.amtha@trisakti.ac.id
}

\begin{abstract}
$\overline{\text { Abstract - Oral cancer is one of the malignancies with high morbidity and poor survival rate. The number }}$ still increases in all countries including Indonesia. Oral cancer is a malignancy that can be prevented by looking at clinical signs known as pre-cancer. Early detection is one of the solutions. The community service was conducted online among cancer survivor community namely Love and Healthy Tangerang to increase the knowledge of oral cancer. The information of recognizing early clinical signs of oral cancer, the risk factors, step-by-step oral self-examination (SAMURI), and how to maintain oral health were given on 50 participants for 3 hours. All of the participants were female with an age range of 32-64 years old. The training were evaluated by undertaking a pre-test and post-test. There was an increase in the mean score of pre-test $66.38 \pm 1,73$ and post-test $80.43 \pm 1,77$, and significant difference among respondents before and after training $(p=0.000)$. The enthusiasm of the participant was very good, seeing from 70 questions were asked during training. By conducting training of early detection of oral cancer with SAMURI, it is hoped that the information can be useful so that the incidence of oral cancer can be reduced. Keywords: oral cancer, early detection, SAMURI,
\end{abstract}

Abstrak - Kanker mulut merupakan salah satu keganasan dengan morbiditas yang tinggi dan tingkat kelangsungan hidup yang buruk. Jumlahnya masih meningkat di semua negara termasuk Indonesia. Kanker mulut merupakan keganasan yang dapat dicegah dengan melihat gejala klinis yang dikenal sebagai prakanker. Deteksi dini adalah salah satu solusinya. Pengabdian masyarakat ini dilakukan secara daring dilakukan pada komunitas penyintas kanker Love and Healthy Tangerang untuk meningkatkan pengetahuan tentang kanker mulut. Informasi tentang pengenalan gejala klinis dini kanker mulut, faktor risiko, pemeriksa mulut sendiri (SAMURI), dan cara menjaga kesehatan rongga mulut diberikan kepada 50 peserta selama 3 jam. Semua peserta adalah perempuan dengan rentang usia 32-64 tahun. Pelatihan dievaluasi dengan melakukan pre-test dan post-test. Terdapat peningkatan nilai rata-rata pre-test $66,38+1,73$ dan post-test $80,43+1,77$, dan terdapat perbedaan yang signifikan pada tingkat pengetahuan pada responden sebelum dan sesudah pelatihan $(\mathrm{p}=0,000)$. Antusiasme peserta sangat baik, terlihat dari 70 pertanyaan yang diajukan selama pelatihan. Dengan diadakannya pelatihan deteksi dini kanker mulut dengan SAMURI, diharapkan informasi tersebut dapat bermanfaat sehingga angka kejadian kanker mulut dapat ditekan.

Kata kunci : kanker mulut, deteksi dini, SAMURI 


\section{PENDAhuluan}

Kanker merupakan salah satu masalah kesehatan di dunia. Di Indonesia, prevalensi penyakit kanker cukup tinggi. Menurut Riskesdas 2018, prevalensi kanker di Indonesia sebesar 1,7 per 100 penduduk atau sekitar 347.000 orang per tahun. Menurut Global Cancer Observatory (GLOBOCAN) 2020, di Indonesia, kanker payudara menempati urutan pertama kanker sebesar $30.8 \%$, diikuti dengan kanker servix, kanker ovarium, kanker kolorektum, kanker tiroid dan kanker lainnya (GLOBOCAN, 2020). Hingga saat ini, data terbaru mengenai kanker mulut secara nasional dari Indonesia, dilaporkan oleh (Cheong dkk., 2017), Indonesia memiliki insidensi kanker mulut sebesar 5.329 dari total 18.071 kasus. Jumlah kasus tersebut menyebabkan kanker mulut di Indonesia menempati urutan ke 6 di Asia Tenggara. Jumlah kanker mulut terus meningkat dengan angka kematian mencapai separuh dari jumlah insidensinya. Demikian pula hal nya pada tahun 2003-2013 jumlah penderita kanker mulut meningkat sehingga masuk dalam 10 kanker terbanyak yang berobat di RS Kanker Dharmais (Purwanto dkk., 2020).

Kanker mulut merupakan salah satu keganasan yang sering didahului oleh tanda klinis dalam mulut yang disebut pre kanker atau lesi yang berpotensi menjadi kanker (Warnakulasuriya dkk , 2007). Kanker mulut adalah penyakit mulut yang dapat dicegah dengan melihat tanda klinis pra kanker (Hook H, 2021). Pada negara berkembang, lebih dari 50\% lesi kanker mulut muncul dari lesi yang disebut sebagai lesi pra kanker atau pre malignant (Villa dkk., 2011). Kenyataan di lapangan, lesi pra kanker ini sering kali terlewati karena kemunculannya tidak menimbulkan rasa sakit. Lesi pre kanker dapat berupa Eritroplakia, Speckled leukoplakia, Lichen planus erosive (van der Waal, 2009). Lesi tersebut dapat dikenali keberadaaanya di dalam mulut dan dapat disembuhkan apabila ditemukan sebelum adanya perubahan pada jaringan yang disebut epitel dysplasia (Ganesh et al., 2018). Lesi pra kanker ini sering kali terlewati karena kemunculannya tidak menimbulkan rasa sakit. Hal ini menyebabkan $70 \%$ kanker mulut ditemukan pada stadium yang lanjut (Warnakulasuriya, 2010) dan memerlukan perawatan yang kompleks, mahal dan lama serta memberikan ramalan ke depan yang buruk. Deteksi pada tahap ini akan menurunkan kesempatan lesi untuk berubah lebih lanjut menjadi kanker mulut yang diketahui amat agresif dan mempunyai prognosis yang buruk. Penelitian di RS Kanker Dharmais tahun 2003-2013 ditemukan bahwa survival rate penderita kanker mulut di Indonesia hanya 24 bulan (Purwanto dkk., 2018), lebih buruk dari jenis kanker lain yang banyak ditemukan di Indonesia. Jumlah kanker mulut terus meningkat dengan angka kematiannya separuh dari jumlah insidensinya (Riskesdas, 2018). Kanker mulut merupakan salah satu keganasan yang dapat dapat dicegah dengan melihat tanda klinis yang disebut sebagai pra kanker. Pemerintah telah memiliki kebijakan dan program pengendalian kanker di Indonesia yang menitikberatkan pada deteksi dini dan tindak lanjut dini kanker dan menurunkan angka kematian akibat kanker

Komunitas penyintas kanker Love and Healthy adalah kumpulan penyintas berbagai jenis kanker pada tubuh, terutama kanker payudara. Pada peyintas kanker, upaya pengawasan secara teratur merupakan kewajiban yang harus dilakukan secara berkala, untuk dapat mencegah kemungkinan terjadinya rekurensi (kekambuhan) kanker, penyebaran atau metastasis ke bagian tubuh lain termasuk rongga mulut. Kunci keberhasilan pengendalian kanker mulut terletak pada kemampuan melakukan deteksi dini lesi pre kanker baik oleh penyintas kanker dan masyarakat awam. Selain itu peningkatan pengetahuan mengenai faktor risiko terjadinya kanker mulut serta tanda klinis dini yang menjadi petunjuk adanya kanker mulut juga perlu disosialisasikan dengan suatu kebiasaan sederhana yang dapat dilakukan secara rutin dan berdasarkan hasil analisi situasi antara tim Pengabdian kepada Masyarakat (PkM) dan komunitas mitra diketahui sebagian besar 
tidak pernah mendapatkan pelatihan yang berkaitan dengan kanker mulut. Oleh karena itu, berdasarkan hal tersebut di atas, maka perlu dilakukan kegiatan PkM. Tujuan dari kegiatan ini adalah dapat mencegah terjadinya kanker mulut sejak dini pada penyintas kanker dan pada akhirnya pada seluruh masyarakat Indonesia. Selain itu peningkatan pengetahuan dan keterampilan melakukan deteksi dini kanker mulut secara mandiri dengan metode SAMURI. Adapun Pendekatan pemecahan masalah yang diambil adalah sesuai dengan anjuran Pemerintah RI untuk pengendalian kanker di Indonesia dengan peningkatkan pengetahuan deteksi dini dan tindak lanjut dini kanker, peningkatan kualitas hidup penderita kanker dan menurunkan angka kematian akibat kanker. Untuk mencapai tujuan tersebut tim melaksanakan program pengendalian kanker yang meliputi upaya promotif dan preventif dengan meningkatkan pengetahuan penyintas dan masyarakat tentang kanker mulut. Pendekatan pemecahan masalahnya adalah: Pertama dengan mengadakan kegiatan pemberdayaan komunitas penyintas kanker dengan melakukan pelatihan tentang bagaimana mengenali tanda kanker mulut, apa penyebab kanker mulut dan mendeteksi dini keberadaannya dengan kebiasaan Periksa Mulut Sendiri (SAMURI) serta menjaga kesehatan rongga mulut agar terhindar dari penyakit. Kedua dengan peningkatan pengetahuan mitra ini untuk selanjutnya akan disebarkan kepada masyarakat yang lebih luas.

\section{METODE PELAKSANAAN}

Pelaksaanaan kegiatan diawali dengan persiapan kegiatan yang meliputi koordinasi tim yang terdiri dari beberapa dosen, mahasiswa dan tenaga pendidik. Koordinasi dan pengarahan dilakukan via teknologi daring. Pelatihan akan diberikan oleh 5 orang pemateri dengan judul materi sebagai berikut : Materi pertama tentang mengenal ciri-ciri/tanda klinis kanker mulut; Kedua tentang faktor risiko/ pencetus kanker mulut; Ketiga tentang cara mencuci tangan yang baik dan benar sesuai WHO; Keempat tentang teknik periksa mulut sendiri (SAMURI) dan kelima tentang cara menjaga kebersihan mulut yang benar untuk mencegah penyakit mulut. Materi yang diberikan sesuai dengan kompetensi anggota tim yang terdiri dosen dari bidang ilmu kedokteran gigi, khususnya bidang Ilmu Penyakit Mulut dan Biologi Oral. Bidang ilmu penyakit mulut amat erat dengan kompetensi mengenali tanda-tanda berbagai penyakit pada jaringan lunak mulut termasuk kanker mulut, cara mencegah dan menjaga kesehatan rongga mulut. Sedangkan bidang bidang biologi oral yang erat dengan kompetensinya menjabarkan tentang faktor -faktor yang berperan pada kanker mulut. Gabungan berbagai kompetensi di atas dianggap mampu untuk memecahkan masalah sesuai dengan analisis situasi mitra yang dalam hal ini memerlukan informasi pengetahuan tentang deteksi dini kanker mulut. Prosedur pelakasanan dilakukan dengan cara melakukan pelatihan tentang materi yang telah disepakati dan melibatkan 50 peserta anggota komunitas penyintas kanker Love and Healthy Tangerang dan dilakukan secara daring.

Untuk membantu agar penyampaian materi pelatihan dapat lebih baik oleh peserta, maka kegiatan ini menciptakan e-poster SAMURI, e-book SAMURI dan video SAMURI yang dapat dikirimkan ke peserta melalui whatsapp (WA) dan selanjutnya dapat disebarkan kepada seluruh masyarakat. Pelaksanaan Kegiatan PkM dilakukan pada hari Sabtu, 30 Oktober 2021 dari jam 9.00-12.00 WIB dengan menggunakan platform Zoom. Untuk melihat hasil pelatihan, dilakukan penyebaran kuesioner pre-test kepada peserta pelatihan yang mencakup 15 pertanyaan, dilakukan dengan menggunakan Google Form online, tautan diberikan via WA group sebelum pelatihan. 


\section{HASIL DAN PEMBAHASAN}

Kegiatan PkM berupa pelatihan deteksi dini kanker mulut dengan metode SAMURI berlangsung dengan lancar. Seluruh peserta adalah perempuan (100\%) dengan rentang usia paling muda berusia 32 tahun dan yang paling tua 64 tahun. Distribusi penyebaran peserta berdasarkan usia tampak pada Tabel 1. Sebagian besar penyintas kanker pada komunitas ini berusia pada rentang usia 4352 tahun. Merupakan rentang usia yang paling banyak terserang kanker payudara. Ditstribusi peserta pelatihan berdasarkan pendidikan, tampak pada Gambar 1. Sebanyak 25 orang (50\%) peserta berpendidikan Sarjana (S1). Hal ini sesuai dengan tujuan pelatihan yang bersifat Training of Trainer agar segala informasi dapat diteruskan pada anggota komunitas lain dan masyarakat yang lebih luas lagi. Sebanyak 41 peserta pelatihan merupakan ibu rumah tangga (Gambar 2).

Tabel. 1. Distribusi peserta pelatihan berdasarkan usia

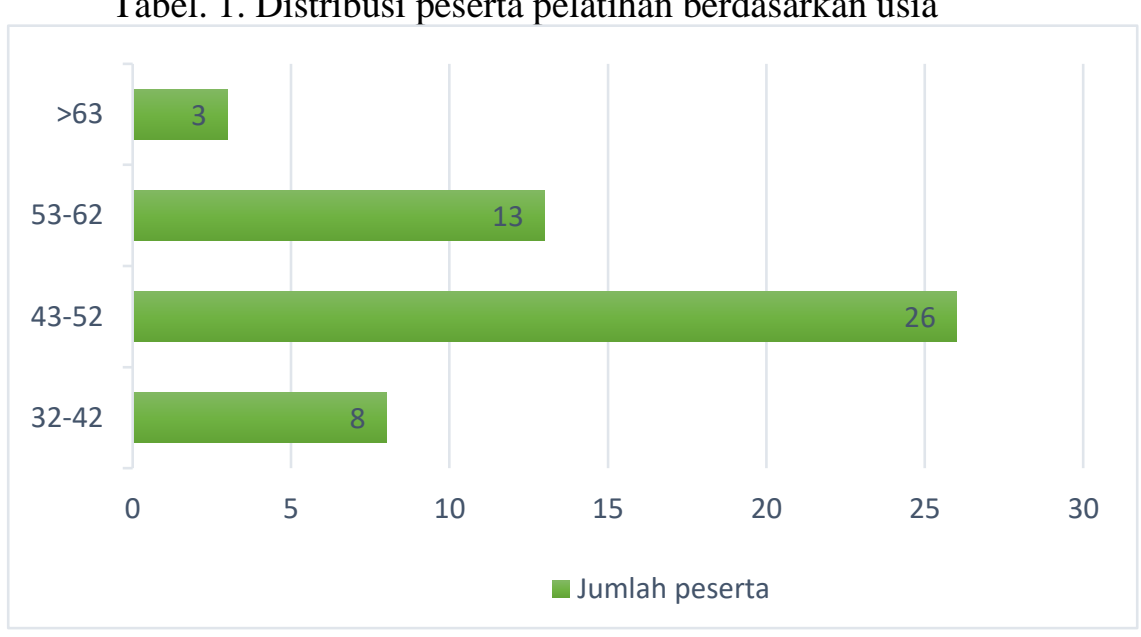

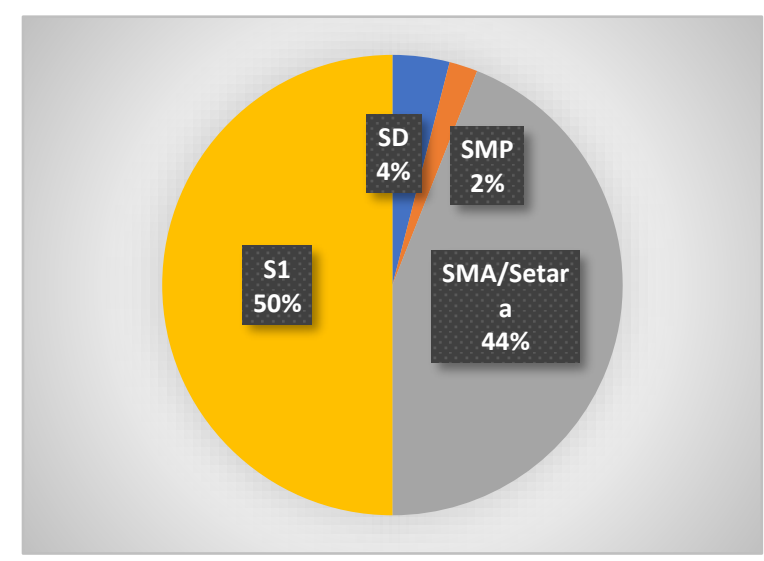

Gambar 1. Distibusi peserta berdasarkan pendidikan terakhir

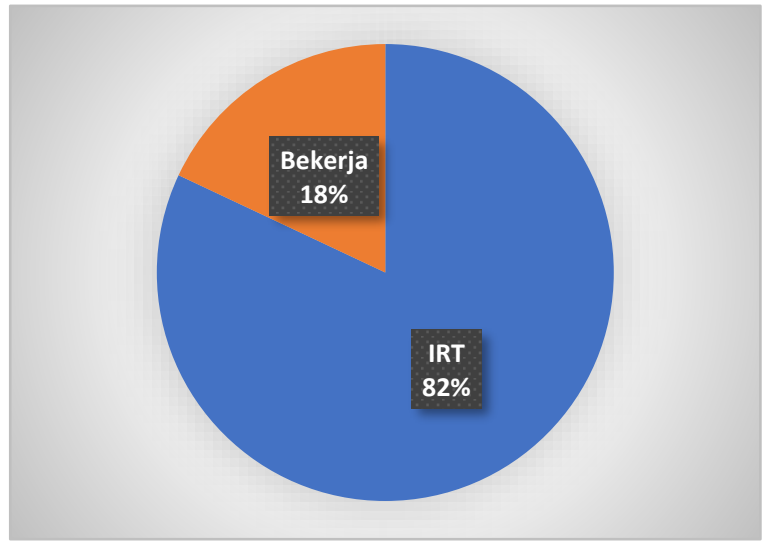

Gambar 2. Distibusi peserta berdasarkan pekerjaan

Kegiatan pelatihan diawali dengan penyebaran flier kegiatan (Gambar. 3) 2 minggu sebelum kegiatan pelatihan di lakukan. Pada saat pelatihan laporan ketua tim PkM menitikbertakan pada tujuan diadakan kegiatan pelatihan dan harapan yang ingin dicapai yang selanjutnya 
sambutan dari perwakilan kordinator komunitas. Materi pertama hingga ke lima (Gambar. 4) disampaikan kuramg lebih selama 2 jam 30 menit dengan lancar oleh pemateri yang diikuti dengan sangat antusias dari peserta, dilihat dari hampir Sebagian besar peserta membuka kamera selama mengikuti pelatihan.

Pelatihan deteksi dini kanker mulut dengan metode Periksa Mulut Sendiri (SAMURI) terdiri dari 9 tahap. Saat melakukan pemeriksaan mulut perhatikan semua perubahan warna, bentuk, kekenyalan, adanya rasa sakit, benjolan atau pembengkakan. Semua temuan tersebut dicatat untuk selanjutnya dikonsultasikan kepada dokter gigi terdekat. Lakukan SAMURI satu bulan sekali. Adapun langkah-langkah SAMURI adalah sebagai berikut (Gambar 5):

1. Sebelum melakukan SAMURI, lakukan cuci tangan dengan menggunakan air mengalir dan sabun, lalu keringkan.

2. Berdiri di depan cermin.

3. Lakukan SAMURI dengan menggunakan ibu jari dan telinjuk kiri dan kanan.

4. Tahap 1 : Buka dan Tarik bibir atas ke atas lalu amati bibr bagian dalam dan gusi atas.

5. Tahap 2 : Buka dan Tarik bibir bawah ke arah bawah, lalu amati bibir bagian dalam dan gusi bawah.

6. Tahap 3 : Buka mulut lalu amati pipi bagian dalam sebelah kanan dan gusi atas bawah kanan.

7. Tahap 4 : Buka mulut lalu amati pipi bagian dalam sebelah kiri dan gusi atas bawah kiri.

8. Tahap 5 : Buka mulut lalu amati area langit-langit

9. Tahap 6 : Julurkan lidah keluar dan amati area punggung lidah.

10. Tahap 7 : Julurkan lidah, dan naikkan lidah ke atas lalu amati area bawah lidah dan dasar mulut.

11. Tahap 8 : Julurkan lidah, dan miringkan lidah ke kanan lalu amati pinggir lidah kiri.

12. Tahap 9 : Julurkan lidah, dan miringkan lidah ke kiri lalu amati pinggir lidah kanan.

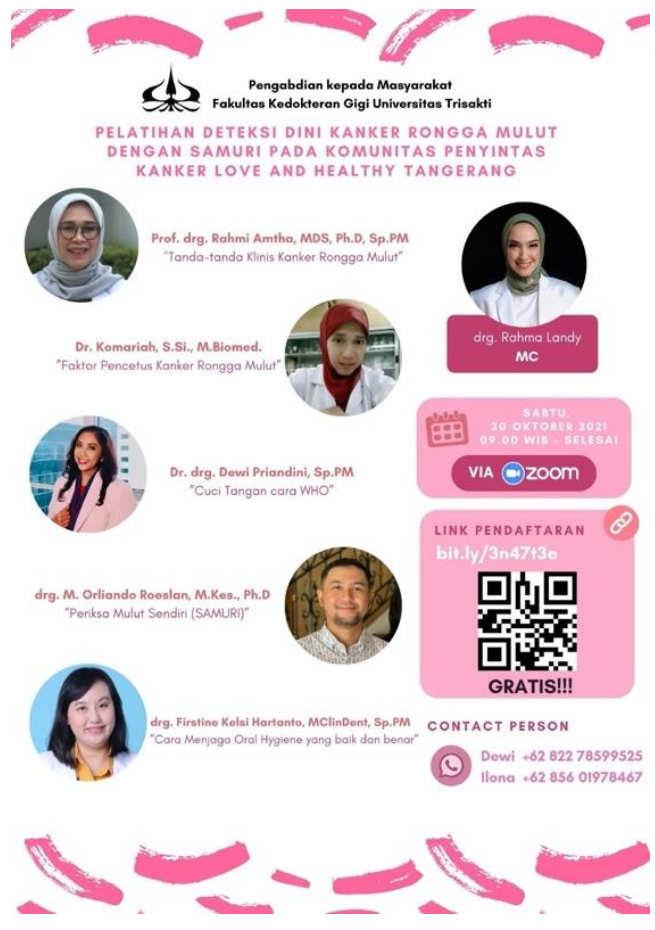

Gambar. 3. Flier PkM SAMURI.

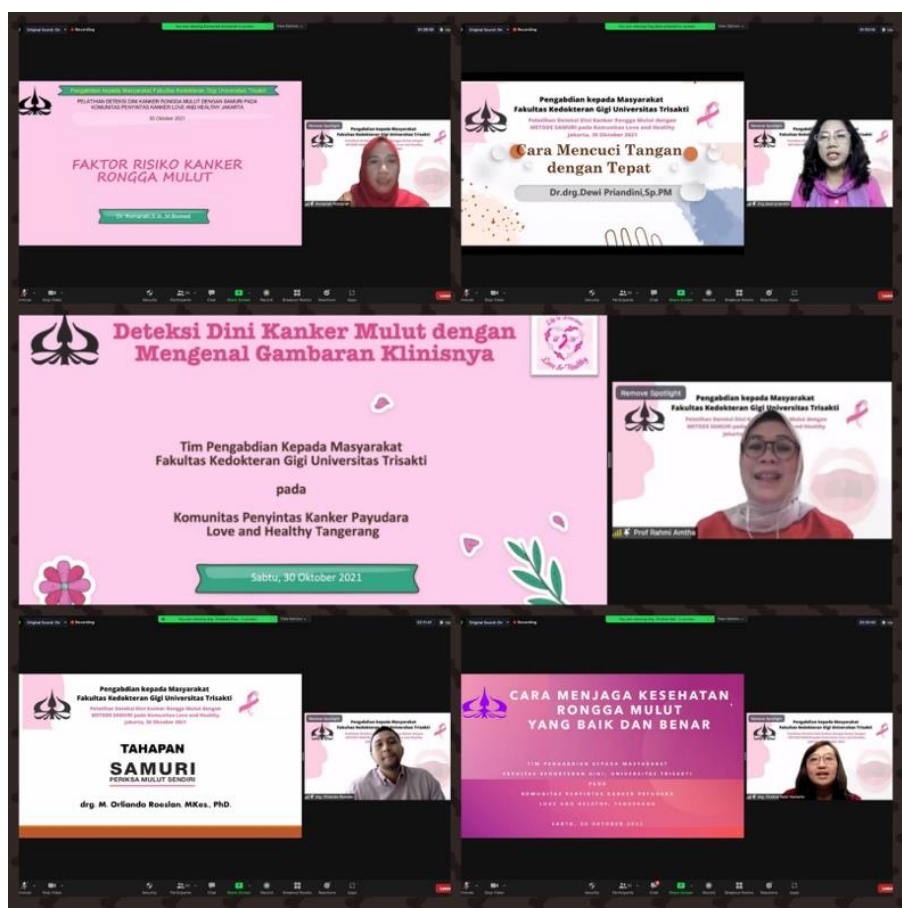

Gambar. 4. Materi Ceramah Pelatihan SAMURI dari semua pemateri 
Tahap-tahap SAMURI dijelaskan satu persatu pada power point dan pemutaran video SAMURI (Gambar 6) dilakukan agar langkah-langkah pemeriksaanya menjadi lebih jelas. Selain itu poster SAMURI (Gambar 7) diberikan kepada mitra untuk dapat diletakkan pada sekretariat komunitas saat kegiatan rutin secara langsung sudah dapat dilakukan paska pandemik berakhir.

Bagi komunitas pelatihan Training of Trainer (ToT) ini merupakan media untuk meneruskan informasi yang didapat dari pelatihan ini kepada masyarakat luas di Indonesia dan menjadikan komunitas ini sebagai salah satu perantara penyebaran informasi mengenai kanker mulut yang masih jarang diketahui. Bagi pelaksana tim PkM yang terdiri dari berbagai unsur prodi atau merupakan bagian dari sivitas akademika FKG Usakti, menunjukkan kemampuan yang amat baik dalam menjalin kerjasama antar anggota dalam tim serta dengan anggota komunitas penyintas kanker yang merupakan bagian dari unsur masyarakat. Tim pelaksana dapat menjalankan unusr Tri Dharma Perguruan Tinggi. Kegiatan PkM merupakan implementasi unsur Pendidikan dan Pengajaran serta Penelitian kepada masyarakat sehingga dapat meningkatkan angka terdeteksinya kanker mulut sejak dini dan menurunkan angka kematiannya.
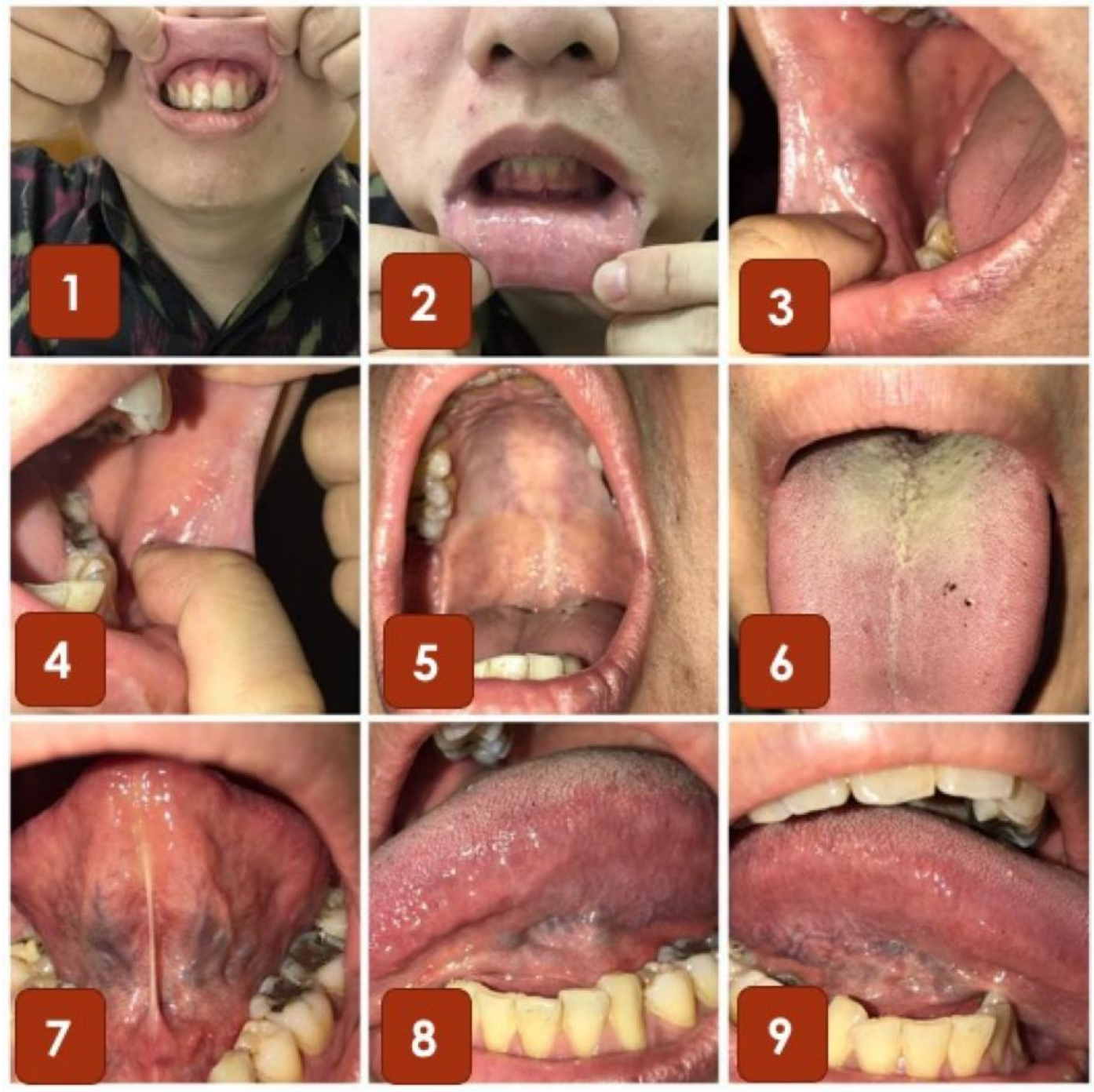

Gambar. 5. Tahapan Periksa Mulut Sendiri (SAMURI) (Amtha, 2019) 


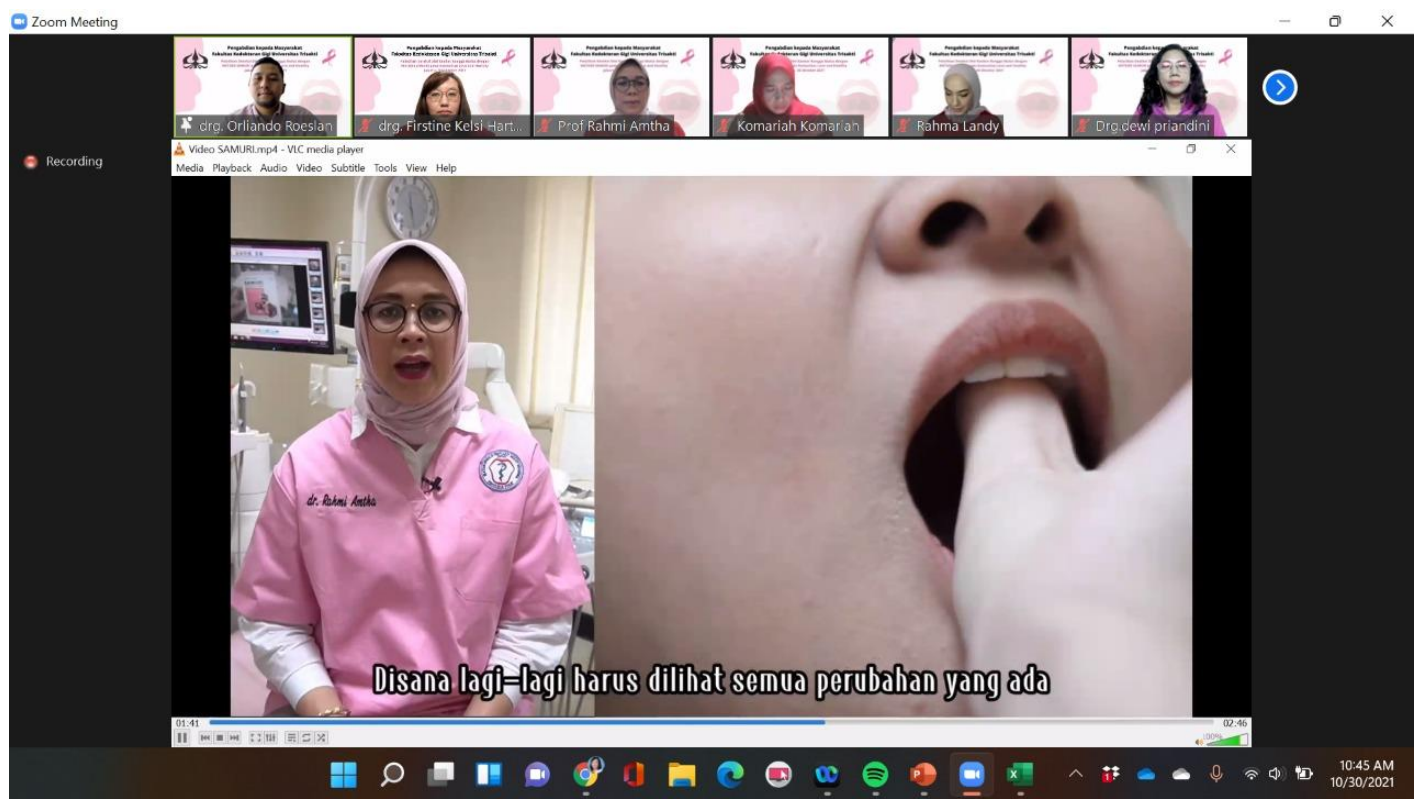

Gambar 6. Pemutaran video langkah-langkah SAMURI (Amtha dkk., 2020)

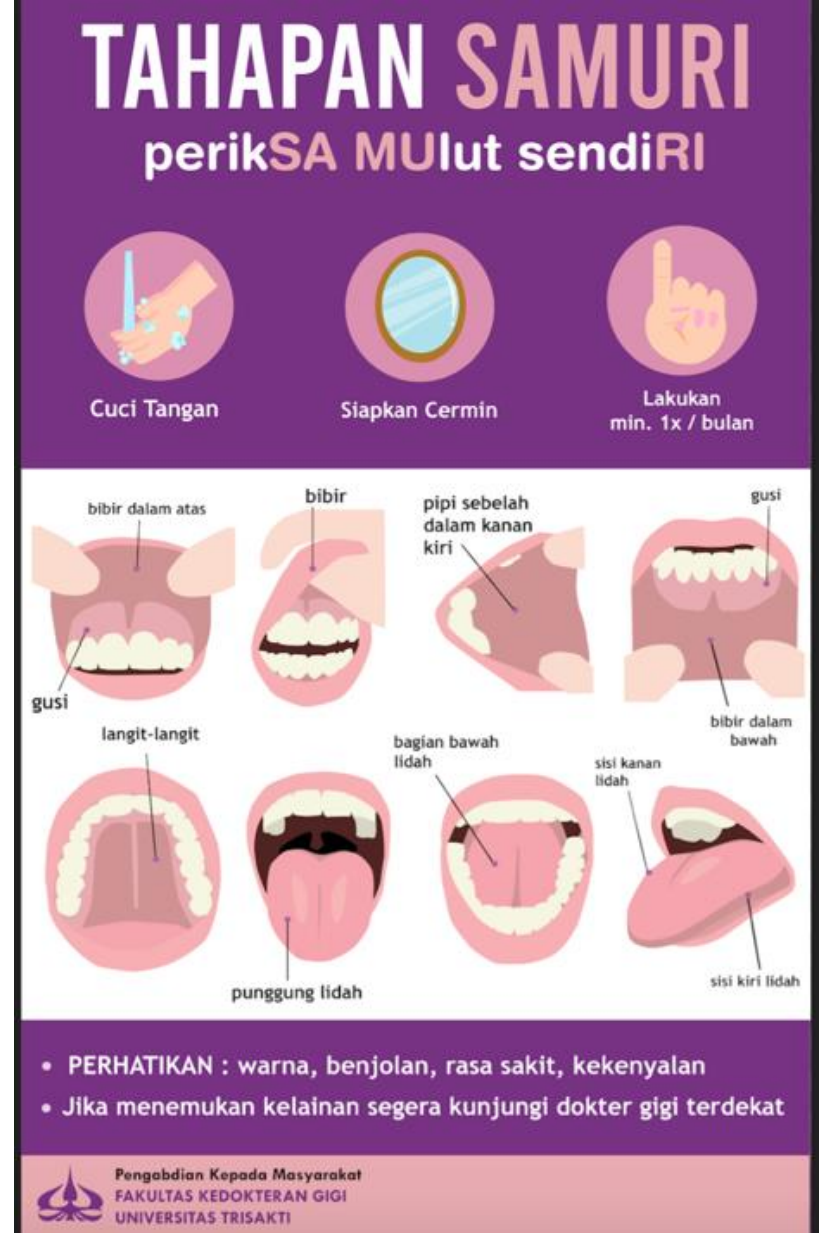

Gambar 7. Poster SAMURI 
Tingkat ketercapaian hasil pelatihan dapat dilihat dari beberapa indikator yaitu Pertama berdasarkan kemampuan peserta pelatihan dalam memahami materi yang diberikan dengan melihat respon selama pelatihan berlangsung (seperti dengan melihat antusiasme peserta dalam mengajukan pertanyaan). Tercatat selama pelatihan sebanyak 35 orang peserta mengajukan pertanyaan secara tertulis pda kolom chat. Masing-masing mengajukan antara 3-4 pertanyaan, sehingga jumlah keseluruhan pertanyaan berjumlah 70. Indikator kedua dengan adanya peningkatan pengetahuan tentang materi yang diberikan sebelum selama dan sesudah pelatihan. Penilaian secara kuantitatif dilakukan untuk mengukur adanya perubahan tingkat pengetahuan peserta sebelum dan sesudah pelatihan dalam bentuk pre test dan post test dengan jenis soal yang sama pada semua peserta. Analisis hasil peningkatan pengetahuan pada 50 peserta yang ikut pelatihan, terdapat 2 orang peserta yang tidak mengikuti pre test dan 3 orang tidak mengisi post test. Oleh karena itu analisis dilakukan hanya pada peserta yang mengisi lengkap pre test dan post test yaitu pada 47 peserta. Nilai rata-rata Pre test $66.38 \pm 1,73$ dan post test $80.43 \pm 1,77$ dengan hasil T-Test terdapat perbedaan bermakna/signifikan $(\mathrm{p}=0,000)$ terhadap pengetahuan peserta sebelum dan sesudah pemaparan materi Tabel 2). Hal ini menunjukkan bahwa kegiatan PkM ini berdampak positif dan bermanfaat bagi peserta.

Tabel 2. T-Test antar kelompok sebelum dan sesudah pemberian materi

\begin{tabular}{llllll}
\hline Kelompok & Mean & SD & SE Mean & 95\% CI & P \\
\hline $\begin{array}{l}\text { Pre Test } \\
\text { Post test }\end{array}$ & 14.04468 & 14.66259 & 2.13876 & $18.35-9.74$ & 0,000 \\
\hline
\end{tabular}

Indikator ketiga adalah dengan mengevaluasi kemampuan peserta pelatihan untuk mengimplementasikan metode SAMURI secara rutin untuk dirinya sendiri, keluarga dan masyarakat lainnya (yang dapat merupakan evaluasi tim $\mathrm{PkM}$ selanjutnya). Tautan Youtube kegiatan pelatihan ini dibagikan kepada anggota komunitas yang tidak hadir. Tercatat sebanyak 207 viewers (penonton) mengikuti kegiatan pelatihan ini (Gambar 8) yang dibagikan saat berlangsungnya kegiatan. Ditriharapkan masyarakat luas lainnya akan dapat melihat ekaman kegiatan ini selama mungkin, sehingga informasi mengenai kanker mulut dapat terus berlanjut.

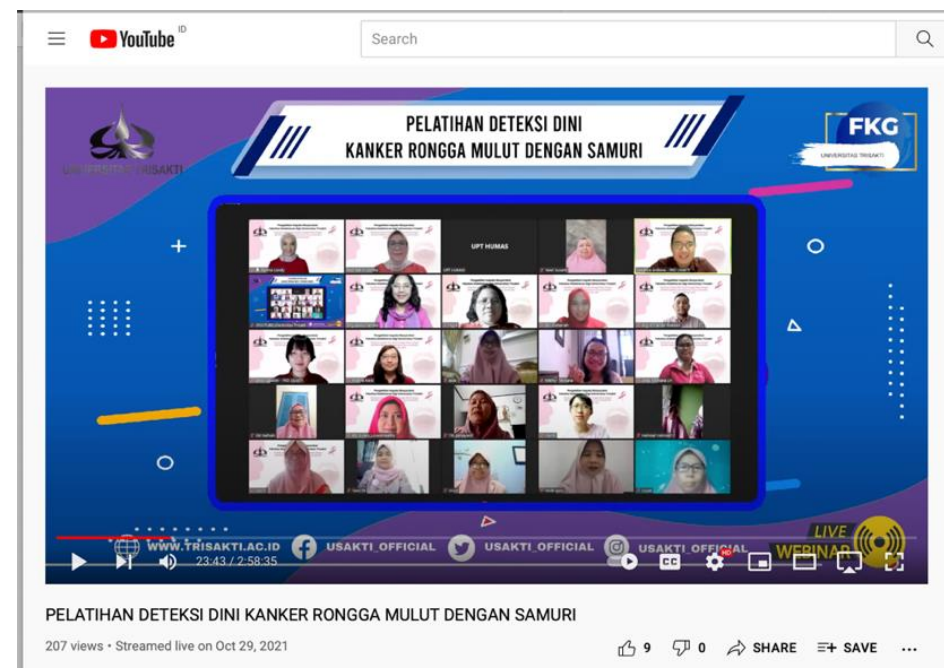

Gambar 8. Kegiatan PkM diikuti oleh anggota komunitas melalui Youtube (“Pelatihan Deteksi Dini Kanker Rongga Mulut Dengan SAMURI - YouTube," 2021) 
Kemampuan peserta pelatihan menunjukkan peningkatan yang sangat baik dengan adanya pelatihan ini, dikarenakan kegiatan ini tidak dilakukan sebelumnya. Penyintas kanker Love and Healthy selama ini telah banyak mendapatkan informasi mengenai kanker payudara serta kanker jenis lain selain kanker mulut yang dianggap sangat jarang terjadi, namun faktor pemicunya sangat erat dengan kebiasaan yang sering ditemukan pada orang-orang sekeliling termasuk anggota keluarganya seperti merokok, minum alkohol dan mengunyah sirih pinang (Amtha dkk., 2014). Sesuai dengan analisis situasi mitra di awal kegiatan, bahwa peserta pelatihan belum mengetahui faktor-faktor pencetus terjadinya kanker mulut, hal ini sesuai dengan teori dan hasil penelitian di Jakarta bahwa tingkat pengetahuan tentang peyebab kanker mulut hanya terbatas pada rokok sebesar 30\%, sedangkan faktor yang lain tidak diketahui (Wimardhani dkk., 2019).

Tanda-tanda awal dari kelainan yang belum menjadi kanker mulut (yang disebut dengan pra kanker) dapat dideteksi dengan melakukan periksa mulut sendiri yang sangat sederhana untuk dilakukan secara rutin sekali dalam satu bulan. SAMURI disarankan dilakukan oleh semua kalangan terutama usia decade ke 3 dan seterusnya, terutama kalangan lanjut usia (lansia) dengan kebiasaan merokok dan faktor pencetus lainnya. Bagaimana cara menjaga agar rongga mulut terhindar dari kemungkinan terjadinya penyakit diberikan melalui berbagai media, terutama di masa pandemi Covid-19 dapat dilakukan secara daring sambil mengajarkan bagaimana menjaga kesehatan gigi mulut di masa ini (Mayasari dkk., 2021).

Kendala selama kegiatan pelatihan berlangsung antara lain ketidakstabilan koneksi internet yang dipengaruhi oleh kondisi cuaca yang sedang hujan deras, namun kestidakstabilan hanya bersifat sementara. Kegiatan PkM ini merupakan implementasi dari hasil integrasi antara pendidikan dan pengajaran dan penelitian yang telah dilakukan sebelumnya dan menghasilkan buku saku serta video tahapan SAMURI yang dapat dimanfaatkan oleh masyarakat. Selain itu PkM ini juga memberikan stimulasi bagi adanya program kreativitas mahasiswa yang dituangkan dalam bentuk kreativitas pembuatan flier kegiatan dan poster tahapan SAMURI untuk diberikan kepada mitra.

Pemeriksaan mulut sendiri (SAMURI) merupakan salah satu cara yang sangat dianjurkan di bidang kedokteran gigi dalam rangka penurunan angka kejadian dan mortalitas akibat kanker mulut. Rekomendasi pelatihan peningkatan pengetahuan tentang kanker mulut kepada masyarakat umum maupun pada masyarakat yang memiliki risiko oleh tenaga kesehatan telah banyak dilakukan diberbagai negara. Salah satu studi randomized clinical trial di India, negara dengan insidensi kematian akibat kanker mulut yang sangat tinggi, melaporkan bahwa angka kematian kanker mulut menurun setelah adanya program pemeriksaan mulut mandiri yang digalakkan oleh pemerintah pada masyarakat dengan faktor risiko oleh tenaga kesehatan (Sankaranarayanan et al., 2005). Peningkatan pengetahuan ini didasari pada model bahwa pengetahuan dan perilaku dipengaruhi oleh pemahaman dan keyakinan individu yang mempengaruhi kesehatannya. Hal ini dikembangkan untuk menjelaskan mengapa seseorang tidak mematuhi perilaku pencegahan atau deteksi dini sebuah penyakit. Pemahaman tersebut akan menuntun seseorang untuk menganggap dirinya rentan terhadap penyakit tertentu (perceived susceptibility), sehingga menyadari bahwa penyakit dapat memiliki konsekuensi yang berpotensi menjadi keparahan (perceived severity). Selain itu yang percaya bahwa tindakan pencegahan akan memberikan hasil yang positif dan hambatan untuk mengambil tindakan pencegahan akan dikompensasi oleh manfaat (perceived benefit) sehingga lebih mampu berpartisipasi secara aktif dalam tindakan pencegahan (Finfgeld dkk., 2003). Pelatihan SAMURI yang hanya memerlukan cermin dan sinar yang cukup perlu senantiasa diadakan pada masyarakat oleh tenaga kesehatan, agar masyarakat dapat membedakan bentuk yang normal dan tidak dari anatomi rongga mulut (Walsh dkk., 2013). Pelatihan yang dilakukan 
secara berkala pada masyarakat terutama dengan faktor risiko kanker mulut (Jornet dkk., 2015) seperti merokok, minum alkohol dan mengunyah sirih pinang terbukti dapat menurunkan insidensi kanker mulut (Elango dkk., 2011).

\section{SIMPULAN}

Kegiatan PkM Pelatihan Deteksi Dini Kanker Mulut dengan Metode SAMURI dilakukan secara daring dengan total peserta sebanyak 50 orang berasal dari komunitas penyintas kanker. Pemberian materi terdiri dari judul: Mengenal tanda-tanda klinis kanker mulut, Faktor pemicu terjadinya kanker mulut, Cara mencuci tangan yang baik dan benar, Tahapan SAMURI dan Cara menjaga kesehatan rongga mulut, dalam bentuk PPT dan pemutaran video. Bahan pelatihan yang digunakan adalah e-poster, e-book, e-video SAMURI dan bahan pembersih rongga mulut. Hasil pelatihan terbukti efektif dalam meningkatkan tingkat pengetahuan peserta sebelum dan sesudah pelatihan secara signifikan $(\mathrm{P}=0,000)$. Selain itu meningkatkan antusiame peserta dengan banyaknya jumlah pertanyaan yang diajukan. Pemanfaatan teknologi dan sistem informasi seperti aplikasi WhatsApp, Zoom dan Google Form menunjang pelaksanaan kegiatan pelatihan secara daring dengan baik.

\section{Ucapan Terima Kasih}

Ucapan terima kasih disampaikan kepada Fakultas Kedokteran Gigi, Lembaga Penelitian dan Pengabdian kepada Masyarakat Universitas Trisakti serta komunitas penyintas kanker Love and Healthy Tangerang atas dukungannya pada tim PkM SAMURI sehingga dapat berjalan dengan baik.

\section{Daftar Pustaka}

Amtha, R. (2019). Hak Cipta: Buku saku Periksa Mulut Sendiri (SAMURI), No. Permohonan EC00201949195, No. Pencatatan 000149062.

Amtha, R., Gunardi, I., \& Kelsi, F. (2020). Hak Cipta: Gerakan Masyarakat Sehat Periksa Mulut Sendiri (SAMURI), No. Permohonan EC00202047660, No. Pencatatan 000216094.

Amtha, R., Razak, I. A., Basuki, B., Roeslan, B. O., Gautama, W., Puwanto, D. J., ... Zain, R. B. (2014). Tobacco (kretek) smoking, betel quid chewing and risk of oral cancer in a selected Jakarta population. Asian Pacific Journal of Cancer Prevention : APJCP, 15(20), 8673-8678. https://doi.org/10.7314/APJCP.2014.15.20.8673

Badan Penelitian dan Pengembangan Kesehatan KEMENKES RI. (2018). Riset Kesehatan Dasar (Riskesdas).

Cheong, S. C., Vatanasapt, P., Yi-Hsin, Y., Zain, R. B., Kerr, A. R., \& Johnson, N. W. (2017). Oral cancer in South East Asia: Current status and future directions. Translational Research in Oral Oncology, 2(1). https://doi.org/10.1177/2057178X17702921

Elango, K. J., Anandkrishnan, N., Suresh, A., Iyer, S. K., Ramaiyer, S. K., \& Kuriakose, M. A. (2011). Mouth self-examination to improve oral cancer awareness and early detection in a high-risk population. Oral Oncology, 47(7), 620-624. https://doi.org/10.1016/J.ORALONCOLOGY.2011.05.001

Finfgeld, D. L., Wongvatunyu, S., Conn, V. S., Grando, V. T., \& Russell, C. L. (2003). Health belief model and reversal theory: a comparative analysis. Journal of Advanced Nursing, 43(3), 288-297. https://doi.org/10.1046/J.1365-2648.2003.02712.X 
Ganesh, D., Sreenivasan, P., Ohman, J., Wallström, M., Braz-Silva, P. H., Giglio, D., ... Hasséus, B. (2018). Potentially Malignant Oral Disorders and Cancer Transformation. Anticancer Research, 38(6), 3223-3229. https://doi.org/10.21873/ANTICANRES.12587

Hook, H. (2021). It's not just about the teeth: The importance of screening for oral cancer and raising awareness. BDJ Student 2021 28:3, 28(3), 28-29. https://doi.org/10.1038/s41406021-0224-4

Indonesia - Cancer Population Fact Sheet - GLOBOCAN 2020. (2020). Diperoleh dari https://gco.iarc.fr/today/fact-sheets-populations

Jornet, P. L., Garcia, F. J. G., Berdugo, M. L., Perez, F. P., \& Lopez, A. P. F. (2015). Mouth selfexamination in a population at risk of oral cancer. Australian Dental Journal, 60(1), 59-64. https://doi.org/10.1111/ADJ.12274

Mayasari, Y., Hertiana, E., \& Mersil, S. (2021). Virtual Edukasi Kesehatan Gigi Dan Mulut Pada Kelompok Lanjut Usia di Masa Pandemi COVID-19. ABDI MOESTOPO: Jurnal Pengabdian Pada Masyarakat, $\quad$ 4(02), 65-72. https://doi.org/10.32509/ABDIMOESTOPO.V4I02.1403

Pelatihan Deteksi Dini Kanker Rongga Mulut dengan SAMURI - YouTube. (2021). Diperoleh Januari 11, 2022, dari https://www.youtube.com/watch?v=-YmeB0wkULs

Purwanto, D J, Reuwpassa, J. O., Adisasmita, A. C., Ramli, M., Djuwita, R., Prihartono, N. A., ... Sari, L. (2018). Neck Dissection in Patients with Oral Squamous Cell Carcinoma in Dharmais Hospital, Jakarta. KnE Life Sciences, 4(4), 144. https://doi.org/10.18502/KLS.V4I4.2272

Purwanto, Denni J., Soedarsono, N., Reuwpassa, J. O., Adisasmita, A. C., Ramli, M., \& Djuwita, R. (2020). The prevalence of oral high-risk HPV infection in Indonesian oral squamous cell carcinoma patients. Oral Diseases, 26(1), 72-80. https://doi.org/10.1111/ODI.13221

Sankaranarayanan, R., Ramadas, K., Thomas, G., Muwonge, R., Thara, S., Mathew, B., \& Rajan, B. (2005). Effect of screening on oral cancer mortality in Kerala, India: a cluster-randomised controlled trial. Lancet (London, England), 365(9475), 1927-1933. https://doi.org/10.1016/S0140-6736(05)66658-5

van der Waal, I. (2009). Potentially malignant disorders of the oral and oropharyngeal mucosa; terminology, classification and present concepts of management. Oral Oncology, 45(4-5), 317-323. https://doi.org/10.1016/J.ORALONCOLOGY.2008.05.016

Villa, A., Villa, C., \& Abati, S. (2011). Oral cancer and oral erythroplakia: an update and implication for clinicians. Australian Dental Journal, 56(3), 253-256. https://doi.org/10.1111/J.1834-7819.2011.01337.X

Walsh, T., Liu, J. L. Y., Brocklehurst, P., Glenny, A. M., Lingen, M., Kerr, A. R., ... Scully, C. (2013). Clinical assessment to screen for the detection of oral cavity cancer and potentially malignant disorders in apparently healthy adults. The Cochrane Database of Systematic Reviews, 2013(11). https://doi.org/10.1002/14651858.CD010173.PUB2

Warnakulasuriya, S., Johnson, N. W., \& van der Waal, I. (2007). Nomenclature and classification of potentially malignant disorders of the oral mucosa. Journal of Oral Pathology \& Medicine : Official Publication of the International Association of Oral Pathologists and the American Academy of Oral Pathology, 36(10), 575-580. https://doi.org/10.1111/J.16000714.2007.00582.X

Warnakulasuriya, Saman. (2010). Living with oral cancer: Epidemiology with particular reference to prevalence and life-style changes that influence survival. Oral Oncology, 46(6), 407-410. https://doi.org/10.1016/J.ORALONCOLOGY.2010.02.015 
Wimardhani, Y. S., Warnakulasuriya, S., Subita, G. P., Soegyanto, A. I., Pradono, S. A., \& Patoni, N. (2019). Public awareness of oral cancer among adults in Jakarta, Indonesia. Journal of Investigative and Clinical Dentistry, 10(1), e12379. https://doi.org/10.1111/JICD.12379 